\title{
SUPERIOR TRIBUNAL DE JUSTIÇA \\ MEDIDA CAUTELAR - MC 014134 - RO (2008/0089908-6)
}

DECISÃO. Trata-se de medida cautelar requerida por UNIMED RONDÔNIA COOPERATIVA DE TRABALHO MÉDICO, com pedido de liminar, visando elidir decisão da Presidência do Tribunal de Justiça do Estado de Rondônia, de sobrestamento de recurso especial (art. 542, § $3^{\circ}$, do CPC), bem como para emprestar efeito suspensivo ao agravo de instrumento interposto e, assim, obstar a realização de cirurgia determinada pelo acórdão do Tribunal de origem, assim ementado: "Agravo de instrumento. Plano de saúde. Liminar pra realização de cirurgia. Risco de vida. Comprovação. Doença pré-existente. Ausência de laudo pericial. improcedência." (fls. 172) Afirma a requerente, em síntese, que o "perigo na demora está exaustivamente demonstrado pela determinação do custeio de procedimento médico de quase $R \$ 20.000,00$ (vinte mil reais) em total confronto com a lei e jurisprudências" (fls.06), porquanto "ausentes os requisitos necessários para realização do procedimento cirúrgico conforme exigências legais", bem como por tratar-se de "doença pré-existente". (fls. 07/09) A irresignação não merece trânsito. No caso em análise, o pedido não apresenta plausibilidade jurídica, pois coloca em debate a ausência dos requisitos ensejadores da concessão da tutela antecipada que, especificamente, determina a realização de cirurgia em paciente com risco de vida. Esse desideratum, pelo contexto dos autos não ostenta, para fins de recurso especial, aparência de bom direito, pela necessidade de investigação probatória que encerra. Com efeito, nas razões do recurso especial a requerente sustenta que o requerido "não deve ter o direito pleiteado haja vista (1) tratar-se de doença pré-existente, (2) não estar presente todos os requisitos necessários para o caso, exigidos pelo Ministério da Saúde e ainda, (3) por não tratar-se de caso de urgência e emergência." (fls. 203) De sua vez, o acórdão recorrido assinala que: "Essas circunstância tem, por si só, o condão de incluir o agravado entre os pacientes com risco de vida (...) Desta forma, o agravado,quando contratou o plano de saúde, estava acima de seu peso, mas não o suficiente para ser considerado conveniado de risco, o que afasta a alegação de que era conhecedor de qualquer doença préexistente. Vê-se portanto, inexistirem elementos que excluam a responsabilidade do agravante para com o tratamento do agravado, mormente pela declaração de fl. 8, onde se atesta a obesidade deste e, pela vigência do contrato, além da aceitação da cooperativa em mantê-lo como usuário dos serviços por si oferecidos, sem nenhuma perícia prévia para aferição de eventual doença préexistente, como alegado no presente." (fls. 174) Portanto, conforme se pode ver, não há como decidir as questões federais suscitadas sem adentrar a seara fático-probatória, o que encontra óbice intransponível na dicção da súmula $7 /$ STJ. Nesse contexto, inviável o especial, o presente pedido apresenta-se evidentemente inapropriado, ante a ausência de plausibilidade. Nesse sentido: "Agravo regimental. Medida cautelar. Efeito suspensivo a recurso especial. Tutela antecipada. Exclusão do nome do devedor no SPC e no SERASA. Multa 
diária pelo descumprimento. Ausência de "fumus boni iuris e de periculum in mora". 1. Não há falar em "periculum in mora", eis que remota, ainda, a possibilidade de execução da multa aplicada pelo Tribunal local em decorrência do descumprimento da tutela antecipada. 2. O "fumus boni iuris", em hipóteses como a presente, está relacionado intimamente com a presença dos requisitos de admissibilidade do recurso especial e com a possibilidade de sucesso deste apelo, daí que, na cautelar, é conveniente apreciar, mesmo que de forma superficial, os requisitos e o mérito do especial, não se podendo desconsiderar a eventual incidência da Súmula n. 07/STJ. 3. Agravo regimental improvido." (AGR-MC 1331/SP, Rel. Ministro CARLOS ALBERTO MENEZES DIREITO, DJU, 31.08.98) "PROCESSUAL CIVIL. CAUTELAR. REQUISITOS ESSENCIAIS. AUSÊNCIA. PEDIDO MANIFESTAMENTE IMPROCEDENTE. NEGATIVA DE SEGUIMENTO. STJ. INSTÂNCIA EXTRAORDINÁRIA. RECURSO ESPECIAL NÃO ADMITIDO. AGRAVO DE INSTRUMENTO NÃO CONHECIDO. TRÂNSITO EM JULGADO. DESCABIMENTO DA MEDIDA. 1 - Constatada, já pela leitura da inicial, a ausência de um ou de ambos os requisitos essenciais a qualquer medida cautelar (fumus boni juris e periculum in mora), a improcedência do pedido é inevitável, não havendo razão, em consequência, para perenizar o processo, sendo de rigor negar-lhe seguimento, ab initio, consoante o art. 34, XVIII do RISTJ e o art. 557 do CPC. 2 - (...)." (AgRg na MC 4.960/RJ, Rel. Ministro FERNANDO GONÇALVES, julgado em 25.03.2003, DJ 07.04.2003) Ante o exposto, manifestamente incabível o pedido, nego-lhe seguimento, a teor do disposto no art. 34, XVIII, do RISTJ. Publicar.

Brasília, 24 de abril de 2008.

MINISTRO FERNANDO GONÇALVES, Relator 